هجلة الفنون والأدب وعلـور الإنسانـيات والاجتهــاع

Journal of Arts, Literature, Humanities and Social Sciences

www.jalhss.com ISSN online: 2414-3383 ISSN print: 2616-3810

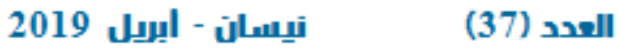

\title{
Communal Frenzy in Khushwant Singh's Novel Train to Pakistan
}

\author{
Assistant Lecturer*, Associate Professor ${ }^{2}$ \\ Mrs. Monika Sharma ${ }^{*}$, Dr. Shashi Sharma ${ }^{2}$ \\ 1Research Scholar, Chaudhary Charan Singh University, Meerut, UP, India \\ Email: monika.sharma@lfu.edu.krd \\ ${ }^{2}$ Department of English, N. A. S. PG Degree College, Chaudhary Charan Singh \\ University, Meerut, UP, India \\ Email: shashiadifeb@gmail.com \\ "Present Address: Department of English, College of Education and Languages, \\ Lebanese French University \\ Erbil, Kurdistan Region, Iraq
}

\begin{abstract}
Discussion about partition which took place post-independence in 1947 . The novel talks about the repercussion of the partition on different communities. Nation went into total chaos leading to massacre and bloodshed. How the lives of common and innocent people are affected due to partition.

The main objective of the paper is to discuss about the communal frenzy and to show the brutal side of humanity at the time of partition.

How Khushwant Singh has depicted the picture of India using a fictional town and the effects of partition on communities living in that town. In this manuscript, Singh indirectly hints that love and passion has the ability and power to win adverse situation.

Discussion about how India was forced to get divided into two separate nations and how arch nemesis was not something people were born but was enforced by colonizers and by Indians too. It creates a paradigm for future studies and exchange of values.
\end{abstract}




\section{INTRODUCTION}

The novel train to Pakistan written by Khushwant Singh is about partition which took place post-independence in 1947. This period is known to be the darkest chapter in Indian history. Post partition people of different communities started killing each other showing the brutal side of humanity and the nation was in total chaos. Singh digs into a deep local focus, providing a human dimension which brings to an event a sense of reality, horror, and believability.

People of $21^{\text {st }}$ century may have read many articles and may have heard many stories from their grandparents about partition but in order to understand and feel the terrible trauma and horror people went through during partition and why different communities were in panicky state, it is important to read the personal accounts of people which the village of "Mano Majra" gives us. "Mano Majra" is shown as the world kin of India post-independence. The harrowing and horrifying events of partition influenced Khushwant Singh to write a novel which portrayed India going through holocaust and how each community was blaming the other one and was finding the reasons to cause massacre and also to prove that one community has the upper hand over the other.

\section{LITERATURE REVIEW}

Different literature majors have approached this novel in different ways and the issue related to the culture and ethnicity and differences in religion. Prof. Kh Kunjo Singh in his study on conflict on cultures and ethnic violence in Khushwant Singh's Train to Pakistan talks about ethnic violence between Hindus and Muslims. It started from Calcutta and became contagious to reach Mano Majra, a multi- ethnic village on the border of Pakistan. Before the riot all the people in the village were intact. But the riot has made them confused and confronted ethnically and culturally. There is a clear reference also to the multi ethnicity in Mano Majra. It is reflected through acute religion fanaticism of one's own. Basically Kunjo Singh is talking about the communal frenzy taking place in not only Mano Majra but the whole country. In train to Pakistan, communalism maybe the stepping stone and Hindu Muslim feeling is the focal point. Kunjo Singh has concluded his study by making a picture of dividing India and its effect in grim reality. Setting all these cultural conflicts and ethnic violence as glaring examples of devastating mankind and the world.

This study explores Dialogism and heteroglossia as explained by MM Bakhtin to analyze the multiple voices and the subsequent dialogic potential in Singh's novel. In this context, it is important to define a dialogic novel. It recognises the multiplicity of perspectives and voices" since "each character has their own final words", which "relates to and interacts with those of other characters". Significantly, "Discourse does not logically unfold but rather interacts", maintaining objectivity and never subscribing wholly to the "ideology of the author" or a singular voice "Heteroglossia in a discourse is diversity of style and voices". 
In the words of Sanjib Kumar, "partition was simply am imposed idea, the translation of which saw lakhs of people massacred and displaced." Partition resulted in loss of homes, identities and faith in nationalism.

\section{DISCUSSION AND ANALYSIS}

From the beginning of the novel it is clearly seen that the communities' hate each other and that is the reason bloodshed took place and even though different communities of Mano Majra are seen in the light of brotherhood they stereotype each other in order to prove themselves superior over the other.

"Our Hindu women are like that: so pure that they would rather commit suicide than let a stranger touch them. We Hindus never raise our hands to strike women, but these Muslims have no respect for a weaker sex." $\{23\}$

And none of the community takes responsibility of their own actions of what they are doing to destroy the opposite community but Singh clearly blames both Hindus and Muslims and hold them accountable for their deeds and actions.

"Muslims said the Hindus had planned and started the killing. According to the Hindus, the Muslims were to blame. The fact is, both sides killed, both shot and stabbed and speared and clubbed. Both tortured. Both raped." $\{1\}$

Where primarily there arises communal frenzy in the novel, Singh brilliantly through the character of Iqbal personifies multi-cultural ethnicity. His religious background is not clear and he is also portrayed as a social worker who is not supposed to be biased to any particular religion which further confuses the reader about his identity about his caste. Iqbal comes to Mano Majra to raise awareness about land reform and to encourage peasants to demand more political and economic rights. He privately identifies himself as 'comrade', suggesting that he works for a communist organization. He is described a small, somewhat effeminate man and was educated in England. But instead he sees the situation of Mano Majra different from what he assumed as the only Hindu is murdered the night before he came and the village is in chaos and suspicion. Iqbal, when first met meet Singh, bhai of Gurudwara, chose not to reveal his religion and for his own convenience went with the name Iqbal Singh when meet Singh called him so. He neither corrects nor denies him which perhaps further symbolises his multi-cultural ethnicity.

"He did not have to say what Iqbal he was he could be a Muslim, Iqbal Mohammed. He could be a Hindu, Iqbal Chand, or a Sikh, Iqbal Singh. It was one of the few names common to the three communities. In a Sikh village, an Iqbal Singh would no doubt would get a better deal, even if his hair was shorn and his beard shaved, than an Iqbal Mohammed or an Iqbal Chand. He himself had few religious feelings. $"\{38\}$ 
Iqbal has a touch of Hindu, Muslim and Sikh. He in that sense is coalescing of those communities. His religious background is not fully revealed or perhaps we can say that readers are confused about Iqbal's character. Still he was not fully biased for any particular community.

Furthermore, Iqbal was accused falsely of the murder of Lala Ram Lal and is thus arrested and put in jail. He quickly became known in Mano Majra as political agitator and so he was also falsely identified as a Muslim who is working for a Muslim league. Yet again the readers can see that his real identity remains uncovered as he was checked by sub inspector and perhaps was found circumcised.

Before the riot there can be seen cultural harmony between the communities which created a mutual understanding. People of different sects, races and religions lived together. But in spite of this 'mutual-cultural understanding', Mano Majra missed the sense of brotherhood. People of Mano Majra misunderstood their 'understanding of mutual-cultural harmony' as brotherhood. The actual communal frenzy becomes evident in the novel with the arrival of the ghost train. This arrival of ghost train breaks the sham of brotherhood which the communities of Mano Majra portray. It implants the seeds of distaste and resentment in the minds of Sikh community against the Muslims as the train carried dead bodies of Hindus and Sikhs, which were coming back from Pakistan. If seen from another aspect, this arrival also instils some emotions in the minds of Muslim community like that of horror and dread. When the train arrives the dark clouds of deafening silence hover over the village, no one wants to talk with each other as the people of village know that two polar opposite communities are residing and 'the talk' will result in immediate violence.

\section{"That evening for the first time in the memory of Mano Majra, Imam Baksh's sonorous cry did not rise to heavens to proclaim the glory of God."(89)}

Riots between two communities cannot only germinate from physical violence done against the other community but can also take birth from an emotion such as love this situation is explained well by Singh in his novel when Juggut Singh's mother rejects the idea of his son impregnating a girl without marriage that too, a Muslim girl. In midst of all this panic and chaos Juggut Singh chose to love a Muslim girl and the first thing he did after getting bailed out of prison he went in search of Nooran, his lover and got to know that all the Muslims of Mano Majra are being forced to go to Pakistan due to safety reasons. Juggut Singh without giving a thought to his safety, decided to save the people in the train by letting go the train and so instead of choosing the hand of his own community he chose the hand of the opposite enemy community. If he would have not died in the process of saving the people in the train, he would have been beaten to death by his own community people because what he did was unjust according to his community.

Another character similar to Juggut Singh is Hukum Chand. He also was infatuated with a Muslim girl, Haseena, who was a sixteen year old prostitute, just like Juggut 
and was ready to take the extreme measures to save her from the brutality which Sikh community was ready to partake. Character of Hukum Chand is painted as culturally conflicted. His opinions regarding the Muslim community changed after meeting Haseena, and it was because of her, he bailed out Juggut and Iqbal from jail and cleared their names from any kind of suspicion or crime which they might've or might've not committed.

Meet Singh is another character who is a hard core Sikh and thus does not considers other religion like Christianity moral. They have exchanges of their wives and they dance and Drinks in the clubs. These are very much different if compared to Hindus and Muslims codes of conduct. This shows that there is no respect for the cultures and traditions of other communities. Meet Singh meets Iqbal in the Gurudwara and gives him a room to stay in the Gurudwara. Here, meet Singh without asking him assumes that Iqbal is Sikh and calls him 'Iqbal Singh'. A reader might think and question that had Iqbal denied his caste as a Sikh and had been a Muslim in reality, then would've meet Singh given him a place to stay?

\section{"Iqbal Singh? Queried the old man. Without waiting for an answer, he continued. 'I'm the bhai of the temple. Bhai Meet Singh." $\{38\}$}

If Iqbal were to belong to a Muslim community, it can be questioned whether meet would've given him place to stay or not or even if would've, then was that out of communal respect and humanity or to save his own reputation and respect in Mano Majra? Neither Meet gave a chance to Iqbal to reveal his own identity nor Iqbal himself do such thing. The quietness of Iqbal cleared the suspicion of him belonging to any other caste, other than Sikh, in the mind of Meet Singh, which earned a place to stay for Iqbal, but clouds of confusion were created in the minds of the readers.

Khushwant Singh has shown meet Singh as the 'man of his own culture', who does not respects other communities but still meet Singh does not want to indulge in horrendous activities which include bloodshed and violence especially of those people with whom he shares his own village even though they belong to different community. And so he tries to keep up with the debate that is coming from the opposition to persuade other Sikhs to kill the Muslims that are going to Pakistan to have proper revenge.

The story takes a sharp turn when Muslim community were evacuated from Mano Majra and were forced to go to Chundunnugger and from thereon to Pakistan. When Muslims came out of their houses to leave Mano Majra, other villagers also came out of their houses to see them off and became emotional. This emotional site of the villager's shows that despite of belonging from different cultures and having ethnic issues both Muslim and Sikh communities used to share a common routine before partition which is engraved in their minds and forever will reside there. Their understanding was so authentic that they could feel each other's pain. 


\section{"The Sikhs watched them till they were out of sight. They wiped the tears of their faces and turned back to their homes with heavy hearts. "\{145\}}

This kind of frenzy gives birth to people like Malli and his gang of dacoits who use the situation to their own advantage. Malli was the one who was trusted to keep the belongings of Muslim people safe till the time they return. But what he did was not expected of him and thus he betrayed his own people by looting their things and ran away with them.

"Malli's gang and the refugees then unyoked the bullocks, looted the carts, and drove the cows and the buffaloes away." $\{145\}$

The most horrifying and heinous incident of this novel which furthers the panic of the people of Mano Majra is when they find corpses floating in the river. Their horror escalates when they receive the information of the arrival of one more ghost train which could've been come from Pakistan and carrying loads of dead bodies. The sight of dead bodies in the river scare the villagers and they conclude that a massacre has taken place somewhere upstream but their expectations of no more violence breaks off when they return to their village and hear about the arrival of the second ghost train. Villagers describe dead bodies that they found in rivers as 'an old peasant with a grey beard lay flat on the water. His arms were stretched out as if he had been crucified'. Even the children and women were pitied upon and they were mutilated mercilessly. 'A child's head butted into the old man's armpit. There was a hole in its back'. Women were brutally tortured 'some had their bellies torn opened; many women's breasts were slashed. They floated down the sunlit river, bobbing up and down.

Khushwant Singh has brilliantly written minute and simple things in such a way that the reader will be able to relate the scenario with that of panic and partition. The imagery that he has used is taken from nature and his language is earthly which is expected from a serene environment of the village.

"Then the bulldozer woke up again. It opened its jaw and ate up the earth it had thrown out before and vomited it into the trench till it was level with the ground. The place looked like the scar of a healed-up wound.” $\{152\}$

The panic and frenzy comes at a peak when some men dressed in khaki uniform and had rifles slung on their shoulders entered the Gurudwara and taunted the villagers by asking them whether they are potent or impotent. These outrageous words were being spoken to invoke the manhood of the Sikh villagers so that they could fight with those people whom they once lived with. These religious fanatics entered the Gurudwara with the main aim to persuade villagers to create more violence in a more brutal sense than the enemies created. 
"For each Hindu or Sikh they kill, kill two Mussulmans. That will stop the killing on the other side. It will teach them that we also play this game of killing and looting." $\{157\}$

The fanaticism of Muslims and Sikhs was heard in meet Singh's "Wah guru" and Imam Baksh's "yah Allah". A cultural contact can be seen in this invocation of god which also became a reason for cultural combat. The men dressed in khaki uniform manipulated the Sikhs by giving religious connotations.

"Besides, the guru himself had Muslims in his army . ..” “. . . and one of them stabbed him while he slept.” $\{158\}$

The only person who was against this extreme violence was meet Singh. He tried to change the thoughts and Mind set of his co-villagers but no one paid heed to him and was insulted.

“'Let him be. He is an old bhai. Let him stick to his prayers,' said many in chorus.” \{158\}

The respect, love and emotions Sikh villagers had and portrayed when Muslim villagers were forced out of Mano Majra went into drainage and thus they were easily manipulated and duped to kill the same people they once used to share their lives with.

\section{CONCLUSION}

To conclude, it can be said that Train to Pakistan is a novel of brutal violence that takes place between two communities at the time of partition of India in 1947, with a hint of sympathy and love, again between the two communities. Though the novel describes the communal riots and holocaust of 1947 still love and compassion are intricately woven in it. In the midst of chaos and bloodshed, it's the innocent people who suffer more as compared to those who have caused it. Khushwant Singh has indirectly targeted the political leaders and their inability to use their power, apart from money making, and to take an action to stop the massacre. This novel looks more like a personal account of an individual who has been through this environment and situation of bloodshed and violence as Singh has painted the picture of horror and terror so realistically. Singh indirectly hints that love and passion has the ability and power to win even in this chaotic situation when world is so adamant in tearing you apart.

\section{REFRENCES}

1. Kh Kunjo Singh. 2014. Conflict of cultures and ethnic violence in Khushwant Singh's Train to Pakistan

a. Chapter-6 politics of partition in Train to Pakistan

b. Chapter-2 Khushwant Singh's Train to Pakistan and its film version 
العدد (37)

2019 iيسان - ايرِل

مجلة الفنون والندب وعلوم الإنساتيات والاجتهاع

2. Dr Rafat Khanam. 2016. Theme of love and sacrifice in Khushwant Singh's Train to Pakistan.

3. Manoj kumar grover. 2017. Socio political consciousness of Khushwant Singh in Train to Pakistan.

4. Sk. Khamar Jahan.2016. Khushwant Singh's Train to Pakistan as a transcendent representation of partition.

5. Pippa Virdee and Arafat Safdar. From Mano Majra to faqiranwalla: revisiting the Train to Pakistan

6. Syrrina Ahsan Ali Haque. 2015. Khushwants Singh's Train to Pakistan: The Heteroglot world of Sikhs, Muslims, and Hindus in a Sikh village.

7. Alok bhalla. 2006. partition dialogues: memories of a lost home

8. Harish raizada.1988. "Train to Pakistan: a study in crisis of values" 